\title{
Understanding how city networks are leveraging climate action: experimentation through C40
}

\author{
Thi Minh Phuong Nguyen ${ }^{1 *}$, Kathryn Davidson ${ }^{1}$ and Lars Coenen ${ }^{2,3}$
}

\author{
* Correspondence: thiminhphuong. \\ nguyen@student.unimelb.edu.au \\ ${ }^{1}$ Faculty of Architecture, Building \\ and Design, The University of \\ Melbourne, Melbourne, Australia \\ Full list of author information is \\ available at the end of the article
}

\begin{abstract}
Climate change is one of the most challenging environmental and social problems for contemporary urban planning. In response to this phenomenon, city networks have emerged as new configurations of urban climate governance that encourage the implementation of experiments such as testing new solutions regarding sustainable transport. While city networks are gaining momentum and influence as effective platforms to transform and scale up pilot experiments into city-wide schemes, little is known regarding their role in conditioning and leveraging such urban experiments Our paper investigates the underexplored nature of urban experiments within city networks and provides a better understanding of how these networks condition urban experiments. To this end an analytical model has been developed and applied to the case of the C40 Climate Leadership Group (C40) and its Climate Positive Development Good Practice Guide. Our findings suggest that the C40 encourages variation in local climate experiments and the generation of new and innovative climate solutions in member cities. In particular they reveal that the implementation of climate positive experiments has passed the 'variation' stage, is currently in the 'selection' stage, and likely to move towards the 'retention' stage in the near future. Potential experimentation outputs of the case are identified as built environment change, new citizen practices, policy change, infrastructural change and new technology. Noticeably, we consider that the C40 plays an important role in providing fundamental institutional support to implement and leverage climate projects within its member cities.
\end{abstract}

Keywords: Experimentation, City networks, C40, Climate action, Governance

\section{Policy and practice recommendations}

1. Urban policymakers and practitioners should understand the role of city networks in conditioning and leveraging urban experiments to derive more benefits from engaging in networking activities.

2. 'Good-practice' climate experiment programmes are often not set-up to test solutions in tightly controlled environments, but rather to encourage the generation of new and innovative solutions.

(C) The Author(s). 2020 Open Access This article is licensed under a Creative Commons Attribution 4.0 International License, which permits use, sharing, adaptation, distribution and reproduction in any medium or format, as long as you give appropriate credit to the original author(s) and the source, provide a link to the Creative Commons licence, and indicate if changes were made. The images or other third party material in this article are included in the article's Creative Commons licence, unless indicated otherwise in a credit line to the material. If material is not included in the article's Creative Commons licence and your intended use is not permitted by statutory regulation or exceeds the permitted use, you will need to obtain permission directly from the copyright holder. To view a copy of this licence, visit http://creativecommons.org/licenses/by/4.0/. 
3. The analytical model we suggest can support urban climate governance regarding the role and nature of climate experiments driven by city networks.

\section{Science highlights}

1) The $C 40$ network plays an important role in conditioning urban climate experiments.

2) The C40 network encourages variation in local climate experiments and the generation of new and innovative climate solutions in member cities.

3) Although C40's climate positive experiments are not yet completed, various potential experimentation outputs have been identified.

\section{Introduction}

In the past 20 years, it has been widely recognised that humanity has entered the 'urban age' (Brenner and Schmid 2014). That is, cities and urban settlements currently accommodate more than $50 \%$ of the population around the world, which is a significant increase from only $2 \%$ in 1800 (United Nations [UN] 2016). Moreover, it is projected that approximately two-thirds of the world's population (i.e., approximately 7 billion people) will reside in cities by 2050 (UN 2014). In this present context, cities and their related urban activities are considered primary sources of anthropogenic carbon dioxide that generate more than 70\% of global emissions (UN-Habitat 2011).

Further, different studies have demonstrated that various urban challenges, including poverty, environmental pollution and climate change have concentrated risks within cities and urban areas, making them increasingly vulnerable to a wide range of threats and hazards (International Federation of Red Cross [IFRC] 2010; UN Environment Program [UNEP] and UN-Habitat 2009). For example, in 2018 Cape Town (South Africa) became the first major city to risk running out of potable water. Other cities that are currently in water crisis include Beijing (China) and Sao Paulo (Brazil) (Wright 2018; Leahy 2018). This vulnerability to risk means that cities play a critical role in enhancing the prospects of humanity through managing various global threats, including climate change.

As noted by Leffel and Acuto (2018), cities are also increasingly considered pivotal to different multilateral agendas that are designed to shape the world's future. Bulkeley et al. (2014) note that climate politics is not limited to international and national forums, and that cities are an important force in pursuing climate governance in their own right. Since the establishment of Local Agenda 21, city governments worldwide have contributed to developing new institutional arrangements for sustainable urban development, and 'continue to do so as [ ...] evidenced by the recently established "Global Parliament of Mayors"' (Raven et al. 2019, p. 259). Additionally, the 21st Conference of the Parties [COP21] in Paris (2015) also witnessed the massive presence of over 400 city mayors and a significant number of side events specifically concentrating on cities (Tollin 2015). Such activities have demonstrated that cities can play a crucial role in developing and implementing innovative solutions to mitigate threats arising from climate change locally and globally (Hale 2016). Given that cities are 'open, complex, dynamic systems with a global reach' (Bai et al. 2018, p. 25), their responses to climate change challenges vary. Cities not only experience climate threats in different ways, but also 
'have historically organised infrastructure provision that may differ and a variable capacity at an urban scale to respond to the emerging pressures' (Hodson and Marvin 2010, p. 481). Accordingly, the contextual realities of urban places may contribute to developing 'a highly variegated "landscape" of supporting and hindering forces' that affect their responses to climate change (Coenen et al. 2012, p. 971).

Moreover, cities are considered particularly critical places for the emergence and unfolding of sustainability transitions and associated system innovations driven by experimentation (Loorbach and Shiroyama 2016; Fuenfschilling et al. 2019; Frantzeskaki et al. 2017; Moore et al. 2018). In this context, a new form of city leadership has developed that favours 'experimentation' as a new approach of city governance (Boyd and Ghosh 2013, p. 926; Laakso et al. 2017;McGuirk et al. 2015; Bulkeley and Broto 2013). At a general level, it refers to a variety of responses occurring within metropolitan locations in the form of 'purposive interventions designed to respond to the imperative for climate change responses in the city, and with more or less explicit attempts to innovate, learn or gain experience' (Bulkeley and Broto 2013, p. 362). In spite of its popularity, there is a lack of consensus and analytical precision on the definition of 'experimentation' giving way to considerable interpretative flexibility across different literature and disciplines (see below).

This paper is particularly concerned with the nature of these experiments becoming increasingly international given that more cities are formalising cross-boundary collaborations with different peers and global actors to accelerate their experimental approaches. International city networks such the C40 Climate Leadership Group (C40) have supported the implementation of approximately 14,000 pilot climate actions within cities since 2011. Such networks are currently considered fundamental platforms for addressing climate change at local levels and coordinating distributed actions around the world. Scholars have noted that the C40 is an efficient platform to 'scale up' pilot climate projects into city-wide schemes (Kronsell and Mukhtar-Landgren 2018; Heijden 2016). There has been mention in research of the networked character of many experiments (Evans et al. 2016). Existing studies have also highlighted the importance of city networks, such as C40, as venues for socialisation, policy learning and collaboration between member cities to support the delivery of experiments (Lee and van de Meene 2012; Lee 2019). However, there exists little research engaging with more fundamental questions of how city networks condition and leverage urban experimentation beyond the aspect of facilitating mutual learning and collaboration between cities. A recent study by Heikkinen et al. (2019), which evaluates anticipated changes in climate change adaptation and mitigation strategies of $\mathrm{C} 40$ cities, also questions the role that city networks can play in the implementation of climate experiments. While city networks are gaining momentum and influence, this lack of research on the more generalised role of city networks in experimentation constitutes a critical gap in the literature (Smeds and Acuto 2018).

To address this research gap, this paper investigates the following two research questions: (1) What is the nature of urban experiments in city networks? (2) What is the role of city networks in conditioning and leveraging urban experiments? Based on research on sustainability transitions, this paper derives an analytical model to illustrate the nature of urban experiments and the role of city networks in leveraging such experiments. The analytical model will then be piloted to assess the case study of C40's 
Climate Positive Development Good Practice Guide. Our review of this guide as the first step in the case-study investigation provides critical insights of experiments driven by city networks.

\section{Experimentation in the context of sustainability transitions and city networks}

The concept of experimentation is one of the central concepts examined in the literature on sustainability transitions, which investigates transformations towards sustainable socio-technical systems' (Sengers et al. 2019, p. 153). Based on the existing body of sustainability transitions literature, the following sub-section 2.1 discusses the background of urban experimentation regarding its varieties, potential outputs and looking 'beyond experimentation'. Next, sub-section 2.2 reviews the literature on experimentation and city networks. This section concludes by outlining an analytical framework that helps to understand experimentation within city networks for sustainability transitions.

\section{Experimentation in sustainability transitions}

\section{Varieties of experimentation}

Previous research has revealed that experimentation can provide new discourses and knowledge, and increase momentum for wider alternatives for policy, technology and institutions (Laakso et al. 2017; Berkhout et al. 2010; Brown and Vergragt 2008). Thus, experimentation can accelerate transformative change within sociotechnical systems through organised processes such as networking and forging alliances, as well as through progressing shared visions and various forms of learning, innovation and collaboration (Berkhout et al. 2010; Nevens et al. 2013). Within the sustainability transitions literature, experimentation is considered to exist in different forms, including niche experiments (Smith and Raven 2012; Hoogma et al. 2002; Weber et al. 1999); bounded sociotechnical experiments (Vergragt and Brown 2007; Brown et al. 2003); transition experiments (Bosch and Rotmans 2008; Bosch 2010); grassroots experiments (Seyfang and Smith 2007; Hopkins 2008); and sustainability experiments (Berkhout et al. 2009; Wieczorek et al. 2015). Each type of experimentation departs from a different theoretical foundation, definition, normative orientation, and analytical emphasis, and considers different key actors (see Sengers et al. 2019) adding to considerable interpretative variety. A recent review by Ansell and Bartenberger (2016) across a range of disciplines arrives at a pragmatic typology of experimentalism.

Given that the type of experiment deployed depends on the particular purpose, which in turn often depends on what is problematic and on pre-analytic values and visions' (Ansell and Bartenberger 2016, p. 65), it is critical to understand the key values, attitudes and purposes of experimentation, and these three factors can be summarised as the 'logics of experimentation': controlled experimentation, Darwinian experimentation and generative experimentation. Controlled experimentation endeavours to understand causality, and thus focuses on carefully controlling different factors that may affect experimental outcomes. Darwinian experimentation aims to enhance systemic innovation through increasing variation. Generative experimentation seeks to create new solution concepts by iteratively and adaptively refining these concepts. These three experimental logics have different uses within different contexts based on their specific 
characteristics. Given that environmental problem solving frequently has multiple objectives, it is possible to combine these three experimental logics to enrich the strategy of experimentation. In addition, it is critical to understand that these three experimental logics 'imply the intention to learn from some intervention' (Ansell and Bartenberger 2016, p. 70). In this sense, learning processes within experimentation can be either epistemic or political or a combination of these two learning types. Ansell and Bartenberger (2016, p. 70) explain epistemic and political learning as follows: epistemic learning is 'learning that expands or refines our scientific knowledge of the world-both of the natural world and the social world', and 'political learning is learning that leads stakeholders to alter their preferences, goals, frames, and commitments'. Table 1 outlines the key attributes of the three logics of experimentation following Ansell and Bartenberger (2016):

Further, it is apparent that there is a strong link between Darwinian and generative logics of experimentation and evolutionary processes of change (Sotarauta and Srinivas 2006). That is, Darwinian experimentation is closely linked with the processes of variation and selection. Ansell and Bartenberger (2016, p. 67) note that the principal value of Darwinian experimentation derives from the idea that 'successful new traits and adaptation to new environments may arise from many trials'. Accordingly, via the production of variation through different trials and the examination which of these trials are successful based on certain specific criteria (which relate to the selection process), there will be more chances to produce new and innovative ideas and efficiently filter out trials that are unsuccessful (Ansell and Bartenberger 2016). Additionally, generative experimentation is linked to the processes of selection and retention. That is, generative experimentation selects to design and re-design only one experiment at a time through accumulated experience and knowledge until that experiment works successfully (Stoker and John 2009). Therefore, it is recognised that generative experimentation 'envisions a continuous iterative process of refinement' to retain the best practice and achieve the most successful outcome (Ansell and Bartenberger 2016, p. 70).

Table 1 Comparison of three logics of experimentation

\begin{tabular}{|c|c|c|c|}
\hline & $\begin{array}{l}\text { Controlled } \\
\text { experimentation }\end{array}$ & Darwinian experimentation & Generative experimentation \\
\hline Characteristics & $\begin{array}{l}\text {-Search for valid } \\
\text { inferences about } \\
\text { cause and effect } \\
\text {-Setting controlled } \\
\text { as much as possible } \\
\text {-Findings aim for } \\
\text { external validity } \\
\text {-Deductive }\end{array}$ & $\begin{array}{l}\text {-Oriented towards variation } \\
\text { through many trials } \\
\text {-ldentifies 'best practices' } \\
\text { but also expects many failures } \\
\text {-Variation more important } \\
\text { than control } \\
\text {-Inductive }\end{array}$ & $\begin{array}{l}\text {-Iterative refinement of } \\
\text { prototype with goal of 'success' } \\
\text {-Discovery and design of new } \\
\text { solutions } \\
\text {-'Success' often depends on } \\
\text { meeting stakeholder expectations } \\
\text {-Abductive }\end{array}$ \\
\hline Allowance for failure & $\begin{array}{l}\text { High (researcher } \\
\text { should not influence } \\
\text { outcome) }\end{array}$ & $\begin{array}{l}\text { Very high (few variations } \\
\text { will be successful) }\end{array}$ & $\begin{array}{l}\text { Low (researcher should strive } \\
\text { for success) }\end{array}$ \\
\hline Innovations vs. routine & Both & Both & Innovations \\
\hline $\begin{array}{l}\text { Observational vs. } \\
\text { interventional }\end{array}$ & $\begin{array}{l}\text { Intervention at the } \\
\text { beginning }\end{array}$ & $\begin{array}{l}\text { More observational than } \\
\text { interventional }\end{array}$ & $\begin{array}{l}\text { Continuous improvement of } \\
\text { intervention }\end{array}$ \\
\hline Examples & $\begin{array}{l}\text {-Randomised control } \\
\text { trials } \\
\text {-Natural and quasi- } \\
\text { experiments }\end{array}$ & $\begin{array}{l}\text {-Parallel experimentation } \\
\text { and benchmarking } \\
\text {-Rapid experimentation } \\
\text {-Simulation experiments }\end{array}$ & $\begin{array}{l}\text {-Design experiments } \\
\text {-Exploratory pilot projects } \\
\text {-Problem-driven iterative } \\
\text { adaptation }\end{array}$ \\
\hline
\end{tabular}

Source: Ansell and Bartenberger (2016, p. 70) 


\section{Outputs of experimentation}

Experimentation can contribute in critical approaches to governance, either through discovering interventions for resolving problems and progressing new practices or through discovering ways for learning about the effects of (small-scale) interventions for developing (larger-scale) interventions (Kivimaa et al. 2017). To better understand the contribution of experimentation to governance, it is essential to investigate the potential outputs of experimentation. Outputs are generated directly from experiments, and these outputs can come in the form of the introduction of a new service or technology (Brown and Vergragt 2008) or in the form of new knowledge about how things work in the real world (Kivimaa et al. 2017, p. 18).

Based on a systematic review of the literature on experiments in climate governance, Kivimaa et al. (2017) recently identified six types of potential outputs from experimentation related to climate governance. First, they identified changed discourse, which refers to new visions or the integration of formerly isolated perspectives. Second, they identified new technology, such as solar water heating or biogas and ceiling insulation. Third, they identified change to the built environment or infrastructure, which refers to change in land-use planning or new low-carbon infrastructure. Fourth, they identify policy and institutional change, which refers to the implementation of new planning practices for improving energy-efficient and eco-efficient construction and the existence of new actors in policymaking at different levels of governance, including the local, municipal and regional. Fifth, they identified new business practices that encourage the development of renewable energy or transport. Sixth, they identified new customer/citizen practices, that enhance citizen engagement and the emergence of alternative communities (Kivimaa et al. 2017, p. 22). Given these potential outputs, Kivimaa et al. (2017) argue that experiments in climate governance could enable system transitions, including changes related to governance, politics and policy.

\section{Beyond experimentation}

Despite the burgeoning literature on experimentation and urban sustainability transitions, 'little is known [about] how the direct outputs of experiments can be reproduced and embedded to achieve significant impact' (Turnheim et al. 2018, p. 5). Recent scholarship also suggests that if 'experimenting is a new means of conceiving of and doing climate governance, then we also expect it to have outcomes beyond the moment of experimentation' (Turnheim et al. 2018, p. 216). Thus, research is required to 'better engage with and understand processes of post-experimentation as existing notions of 'scaling experiments and innovation' are too unidirectional and poorly aligned with the network ontology of contemporary urbanism' (Davidson et al. 2019, p. 12).

Turnheim et al. (2018) argue that to investigate the 'beyond' of experimentation, which refers to the potential influence and embeddedness of experimentation, there are three key dimensions to consider: the temporal dimension, the spatial dimension and the evaluative dimension. In relation to the temporal dimension, city experiments should have a long-term life and create deep alterations or broader implications; for example, the creation of new hypotheses, learning or concepts; the progression of new development paths; the formation of new networks and alliances (Turnheim et al. 2018). Regarding the spatial dimension, there is a need to sustain experiments and their 
outputs across various spaces and scales. This means that the expectations and nature of experiments should be generic, their outputs should be mobile and transferrable to ensure they will contribute to the creation of transformative change (Turnheim et al. 2018). For the evaluative dimension, it is critical to assess an experiment's value proposition and metrics (e.g. in relation to its relevance, effectiveness or efficiency) and whether the experiment can be scaled up or whether its outputs can be transformed to outcomes that will contribute to long-term climate change mitigation and adaptation (Turnheim et al. 2018).

The debate on 'beyond experimentation' has also drawn attention to the relationship between experimentation and institutional change. As sustainability transitions are generally considered to refer to the processes of institutional change (Geels 2004; Fuenfschilling and Binz 2018), many transition researchers (e.g., Kemp et al. 1998; Hoogma et al. 2002; Seyfang and Smith 2007; Smith and Raven 2012) claim that experimentation is a means of inducing change that can potentially lead to a system's fundamental transformation. Previous research highlights that 'experimentation and institutions are closely interlinked' (Fuenfschilling et al. 2019, p. 225). That is, institutional settings determine the form and degree of experimentation, which in turn influence the potential space for change and innovation. For example, Raven et al. (2019) evaluate smart-city initiatives of three cities, one in Germany, one in the Netherlands and one in China to understand how the respective cognitive, normative and regulative institutional arrangements influence these experiments. Their results indicate that the institutional context of each city is unique, and hence generates discrepant versions of smart-city developments. Notably, these researchers also highlight that national policy programmes and governance approaches have a strong effect on smart-city initiative is designed at the city level.

Conversely, experimentation also affect institutions. As suggested by Fuenfschilling et al. (2019), experimentation can serve as a pathway for establishing the pertinent institutional environment for new actors, new narratives and new practices. Experimentation can 'shift informal institutions into the direction of risk-rich spaces for trialling new solutions and altering practice and design elements of dominant solutions' (Fuenfschilling et al. 2019, p. 225), and thus can contribute significantly to facilitating change and innovation. An interesting example is found in Parks (2019), who analyses smart-city experiments in the field of building-energy utilisation in Malmo, Sweden. The study's findings indicate that smart-city technologies have the potential to reshape urban governance, particularly through restructuring the relationship between different actors involved in these technologies, including developers, energy utilities and city authorities.

While previous studies have suggested that experimentation has the potential to become a mode of governance enabling urban sustainability transitions, Fuenfschilling et al. (2019, p. 225) argue that it is critical to 'position urban experimentalism and governance experimentation in a multi-level governance context' that supports the monitoring, evaluation and translation of new learnings generated from local experiments beyond its jurisdictional contexts. Networked or supra-urban governance structures support the (de-)institutionalisation of experiments and act as a backbone that orchestrates and monitors local experimentation. Consequently, further research is needed to gain better understanding of the role of city networks such as the C40 and 100RC and 
whether they can fulfil a similar role as supra-national bodies such as the European Union in monitoring and institutionalising experimentation (Fuenfschilling et al. 2019).

\section{Experimentation and city networks}

\section{Why experimentation has evolved in urban climate governance?}

Also beyond the sustainability transitions field, existing literature on polycentric governance (Jordan et al. 2015) and urban climate governance (Bulkeley et al. 2014) has demonstrated the limited capacity of conventional national and transnational governance structures to resolve complex global problems such as climate change, even after important international agreements such as the Paris Climate Agreement acknowledging there are no given ready-made policy solutions for addressing climate change (Conklin 2006; Bulkeley and Betsill 2005; Partzsch 2017). Instead, 'governing by experiment' has emerged as a potential approach for tackling climate change threats (Bulkeley and Broto 2013). It advocates the idea that small-scale trials of policies, technologies or participatory techniques that are subject to real-world contextual conditions can generate useful information and innovative ways of policy learning (Heilmann 2008; Bruijne et al. 2010; Bos and Brown 2012; Sabel and Zeitlin 2012; Laakso et al. 2017). Simultaneously, it favours the scaling up of successful bottom-up ideas, initiatives and actions (Ceschin 2014; Laakso et al. 2017). Notably, it highlights the increasing importance of citizen participation and processes of democratic engagement and involvement, and the considerable contribution of social media and new digital tools to enabling prompt bottom-up change (Laakso et al. 2017).

\section{Networked city experimentation}

Specifically, Hoffmann (2011) has proposed to conceive networked urban climate action as a form of governance experimentation. Similarly, Smeds and Acuto (2018, p. 551) argue that city networks are crucial to urban climate action because these networks have facilitated experimentation and raised the level of ambition among cities learning from and competing with each other with regard to the deployment of lowcarbon technologies and policies'. In the context of urban climate governance, sociotechnical experiments and governance experiments are identified as two major conceptual strands of experimentation (Smeds and Acuto 2018). While the strand of sociotechnical experiments aims to test new material interventions within urban sociotechnical systems, the strand of governance experiments focuses on developing new approaches for governing these systems (Bulkeley and Broto 2013; Sengers et al. 2019; Bos and Brown 2012). For example, in the transport sector, a sociotechnical experiment can be highly practical (e.g., a bike-sharing scheme), and a governance experiment can potentially empower a city's mayor to initiate new modes of transport.

Moreover, a city network provides a critical context for facilitating and scaling up pilot climate experiments into city-wide schemes (Kronsell and Mukhtar-Landgren 2018; Heijden 2016). Broto and Bulkeley (2013) surveyed 100 cities worldwide, finding that city network membership is a more significant determinant of the number of climate experiments being conducted in a city than are other attributes such as gross domestic product per capita or population. Despite this interesting finding, research on 
the role of city networks in urban experimentation is relatively absent in the contemporary literature.

Given that city networks place great emphasis on the significance of transnational alliances and strategic implementation, municipalities have engaged in new entrepreneurial and public-private partnerships with non-municipal actors, including the World Bank, the UN and the EU (Haselmayer 2018; Acuto 2016). While city networks grow stably in relation to number and variety, Acuto and Rayner (2016) and Smeds and Acuto (2018) report that the diversity of networked actors involved in experimentation extends well outside city chambers.

\section{The practice of orchestration in city networks}

To understand the nature and geographies of networked urban governance and global city networks, increased research attention has been directed towards investigating orchestration. This refers to an ungoverned set of relationships working around a common goal (Gordon and Johnson 2017). That is, as suggested by Abbott et al. (2015), orchestration is a form of indirect governance defined by the weakened relationship between governor and governed-the orchestrator works via an intermediary for governing a target audience. This is a mode of indirect governance that is well tailored to the field of global urban climate governance because it 'helps to capture the different frequencies of power that operate as actors of various sorts seek to produce transnationally coordinated urban climate governance activities and efforts' (Gordon and Johnson 2017, p. 695; Bulkeley and Kern 2009; Allen 2010; Bulkeley 2012).

Gordon and Johnson (2017) identify three distinct modes of orchestration within the field of urban climate governance (specifically city networks): complementary, coordinating and emergent. Complementary orchestration advocates a politics of inclusion, representation and conformity that occurs within formal practices and rules of nation states in a multilateral regime. Coordinating orchestration refers to a politics of authority, contestation and legitimation occurring alongside or outside the multilateral regime. Emergent orchestration refers to subterranean politics of social expectation, structural domination and identity formation. Emergent orchestration illustrates itself within practices, norms and metrics which render cities comparable, observable and governable (Gordon and Johnson 2017). Table 2 presents Gordon and Johnson's (2017, p. 703) example of how the three modes of orchestration work in practice.

Table 2 Three modes of orchestration

\begin{tabular}{|c|c|c|c|c|}
\hline $\begin{array}{l}\text { Orchestration } \\
\text { mode }\end{array}$ & Orchestrator & Intermediary & Logic & Objectives \\
\hline Complementary & $\begin{array}{l}\text { UNFCCC Secretariat, } \\
\text { UNSG, EU Commission }\end{array}$ & $\begin{array}{l}\text { IPCC, ICLEI, Green } \\
\text { Climate Fund }\end{array}$ & Inclusion, Participation & $\begin{array}{l}\text { Bolster regime capacity } \\
\text { and legitimacy }\end{array}$ \\
\hline Coordinating & $\begin{array}{l}\text { Bloomberg } \\
\text { Philanthropies, } \\
\text { Individual cities }\end{array}$ & $C 40, C D P, c C R$ & $\begin{array}{l}\text { Autonomy, Recognition, } \\
\text { Enhancing capacity }\end{array}$ & $\begin{array}{l}\text { Augment governance } \\
\text { capacity and political } \\
\text { capital }\end{array}$ \\
\hline Emergent & Siemens, World Bank & $\begin{array}{l}\text { ISO, GHG Protocol } \\
\text { for Cities, City } \\
\text { Credit Ratings }\end{array}$ & $\begin{array}{l}\text { Competitive standing, } \\
\text { Development, } \\
\text { Trustworthiness }\end{array}$ & $\begin{array}{l}\text { Enhance return on } \\
\text { investment and impact } \\
\text { of capital investments }\end{array}$ \\
\hline
\end{tabular}

Source: Gordon and Johnson (2017, p. 703) 
This typology provides a useful starting point to critically assessing the engagement of cities and different actors in global climate governance. In detail, different kinds of orchestration that rely on different logics of acquiescence will be oriented towards different audiences, and will thus deliver different types of governance outcomes. Accordingly, orchestration is situated 'at the intersection of experimentation and systemic effects' (Gordon and Johnson 2017, p. 707), and potential platforms identified with different orchestrators, intermediaries and targets can facilitate the upscale of urban experiments. However, it is crucial to further progress the research around orchestration to identify whether different orchestrators and intermediaries can create new means of power and political control (Gordon and Johnson 2017).

Understanding experimentation within city networks for sustainability transitions

Our analytical model, which synthesises the above perspectives, is structured with three key steps as illustrated in Fig. 1.

The following section explains the application of the three steps of the proposed model.

\section{Step 1: city experiments}

Step 1 investigates the logics of the experimentation employed in city networks through controlled experimentation, Darwinian experimentation and generative experimentation, and then identifies their links to different processes of the evolution of experimentation, which are variation, selection and retention (Sotarauta and Srinivas 2006).

\section{Step 2: how city networks relate to experiments?}

Step 2 focuses on investigating whether city networks facilitate the process of selection and retention of experimentation via potential platforms identified through the conceptual lens of orchestration as presented in sub-section 3.3.

\section{Step 3: leveraging of a local action into a global network}

Step 3 elicits an understanding of potential outputs from experimentation in city networks. These outputs are changed discourse, new technology, built-environment change, policy and institutional change, new business practices, and new consumer/citizen practices (Kivimaa et al. 2017).

\section{Methodology}

With the aim of illustrating the nature of experiments driven by city networks, this study adopts a qualitative research methodology that employs the case-study approach. As noted by Baxter and Jack (2008, p. 544), a case-study approach 'facilitates

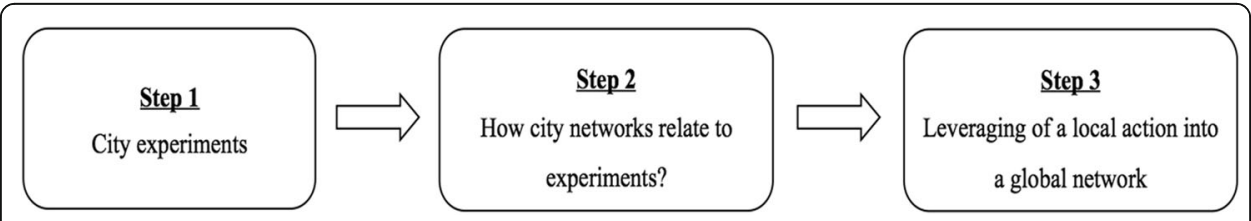

Fig. 1 An analytical model for understanding experimentation within city networks 
exploration of a phenomenon within its context using a variety of data sources'. This methodology ensures that the researched subject is investigated through various lenses, thus providing a holistic approach to understanding different aspects of the case (Punch 2013; Bryman 2012).

In consideration of multiple forms of a case-study approach, a critical case study is selected for application in this paper. Given that a critical case study is designed to understand the strategic importance related to a general issue or problem (Yin 2014), this method is appropriate for exploring the experience of cities participating in city networks in relation to the design and implementation of urban experimentation. This research selected the case study of the Climate Positive Development Program of the C40 network because this network is considered one of the most significant global city climate networks worldwide (Davidson and Gleeson 2015).

The C40 was established in 2005 with the initial membership of 18 cities, and this network grew to 96 affiliated cities in 2019. Before the establishment of the C40, although cities had the ability to address climate change threats, their capacities were limited by poor knowledge exchange and coordination (Acuto 2013, p. 840). With the formation of the C40, Acuto (2013) indicated that this network articulates climate change as an urban-driven question for the first time. The C40 'moved beyond traditional international relations and developed 'network diplomacy' to provide cities with the capacity to participate in global governance discourse (Heine 2008; Davidson and Gleeson 2015, p. 235). The network contributes significantly to facilitating the exchange of governance-related knowledge and resources among members to solve governance-related problems', and thus allow city members to learn, collaborate and socialise (Leffel and Acuto 2018, p. 2; see also Lee 2013). The C40 is also considered as central to the design and implementation of different climate experiments in cities around the world (Smeds and Acuto 2018).

To complement and deepen the efficiency of the network, the C40 has designed a range of programmes to ensure that cities can access to diverse range of support services to more effectively deliver city climate action. Currently, the $\mathrm{C} 40$ has 16 programmes with different experiments, ranging from 'localized direct support, to improved access to data, to broad-based partnered efforts around finance, city diplomacy, and inclusive climate action' (C40 2020, p. 1). The Climate Positive Development Program, which is an initiative launched by C40 cities in partnership with the US Green Building Council and the Clinton Climate Initiative in 2009 supports the development of low-carbon projects for addressing the operational (versus embodied) carbon emissions associated with transportation, energy and waste (C40 2016). Currently, the program has 18 projects, 13 of which are operating in $\mathrm{C} 40$ cities. Together, these projects are expected to reduce the emissions impact for approximately one million residents (C40 2013). Moreover, the 18 projects on six continents, 'supported by local governments and property developers, will demonstrate Climate Positive strategies, setting a compelling environmental and economic example for cities to follow' (US Green Building Council 2020, p. 1). With this scope and ambition, the Climate Positive Development Program (and its associated experiments) is considered as 'a groundbreaking global' initiative of the C40, and thus is worth investigating for the purpose of this research (C40 2013, p. 1).

To investigate the nature of experiments under the Climate Positive Development Program and the role of $\mathrm{C} 40$ to these experiments, this study conducts a document 
analysis in which empirical data are obtained from C40 documents that are publicly accessible for research purposes. Given that this research is illustrative, and aims to apply the developed analytical model, documentary data derived from C40's publications is deemed as the most relevant, valuable and stable sources of evidence to address the study's purposes.

This research focuses on reviewing the Good Practice Guide that reports the progress of the Climate Positive Development Program. In detail, the C40 has published a series of Good Practice Guides that outline the critical benefits of a specific climate action, and successful approaches and strategies for cities to implement or efficiently scale up that action (C40 2016). These Good Practice Guides are developed on the basis of experience of $\mathrm{C} 40$ cities, and are considered valid and important sources of knowledge not only for C40 members but also for other cities around the world (C40 2016). With the release of the Good Practice Guides, the C40 has identified 100 practical and successful climate solutions implemented within member cities worldwide of different geography, size and stage of development (C40 2019). In the C40's guides, a 'good practice' is considered an effective climate action 'leading to better economic, social, and environmental outcomes for cities' (C40 2016, p. 9).

The Climate Positive Development Good Practice Guide has selected and showcased the success stories of four most ambitious low-carbon projects under the program, which include the projects of Royal Seaport (Stockholm), Elephant \& Castle (London), Barangaroo South (Sydney), Mahindra World City (Jaipur) (C40 2016). These four projects were selected by the $\mathrm{C} 40$ as good practices as they met the following criteria: set ambitious goals and utilise holistic planning; create policy and regulatory frameworks to stimulate Climate Positive development in regeneration projects; utilise procurement powers to promote Climate Positive transformation of industrial areas; create sector plans to guide Climate Positive development of mixed-use areas; and maximise the potential of Climate Positive private-public partnerships (C40 2016).

Thus, reviewing these selected cases is likely to generate understandings of how these climate experiments are contributing to emissions reduction and climate change mitigation, as well as how potential outputs of experiments driven by city networks might look like in reality. Further, in the Climate Positive Development Good Practice Guide, the information about the four best model projects is structured under the following four key subheadings: 'Summary', 'Results', 'Reasons for success' and 'When/why might a city adopt an approach like this'.

Given that the data are collected via desk research, document analysis is adopted as the principal technique for analysing data in this study (Bowen 2009). This method is generally considered as a highly applicable approach for qualitative case study research (Bowen 2009). In detail, document analysis involves the iterative process of 'skimming (superficial examination), reading (thorough examination), and interpretation' of relevant documents (Bowen 2009, p. 32), from that the researcher can 'uncover meaning, develop understanding, and discover insights relevant to the research problem' (Merriam 2009, p. 118).

As our proposed analytical model comprises three key steps as 'Step 1: City experiment', 'Step 2: How city networks relate to experiments?', 'Step 3: Leveraging of a local action into a global network', we searched for exact key words or close synonyms that represent key components of each step, as illustrated in the following Table 3. 
Table 3 Key words used for content analysis of the Climate Positive Development Good Practice Guide

\begin{tabular}{|c|c|c|}
\hline Step of the analytical model & $\begin{array}{l}\text { Key component of } \\
\text { step }\end{array}$ & Key words for 'search and find' \\
\hline \multirow[t]{2}{*}{ Step 1: City experiment } & Logics of experiment & $\begin{array}{l}\text { - Controlled logics: 'control', 'cause', 'effect', 'causality', } \\
\text { 'controlling factors', 'high failure allowance'. } \\
\text { - Darwinian logics: 'variation', 'trial', 'best practice', 'high } \\
\text { failure allowance' } \\
\text { - Generative logics: 'success', 'innovation', 'new solution', } \\
\text { 'low failure allowance. }\end{array}$ \\
\hline & Stage of experiment & 'variation', 'selection', 'retention', 'best practice' \\
\hline $\begin{array}{l}\text { Step 2: How city networks relate } \\
\text { to experiments? }\end{array}$ & Role of city network & $\begin{array}{l}\text { 'coordinate', 'recognise', 'actor', 'role', 'participation', } \\
\text { 'networking', 'partnership', 'C40' }\end{array}$ \\
\hline $\begin{array}{l}\text { Step 3: Leveraging of a local } \\
\text { action into a global network }\end{array}$ & Output of experiment & $\begin{array}{l}\text { 'result', 'outcome', 'output', 'new technology', 'new } \\
\text { infrastructure', 'new policy', 'new business practice', } \\
\text { 'new citizen practice' }\end{array}$ \\
\hline
\end{tabular}

Subsequently, we performed a careful read of four projects' descriptions, their good practice approaches, the Climate Development Program background discussion and other sections that have content aligned with or demonstrated obvious grasp of the definition of key components of each step proposed within our analytical model. Finally, we have synthesised all findings drawn from the process of content analysis to identify similarities and differences between four projects presented in the Climate Positive Development Good Practice Guide and address the proposed research questions. Our case study analysis is exploratory as it aims to illustrate the developed analytical model and to reveal early insights into the nature of experiments driven by city networks. The approach is based on document analyses, which necessarily has limitations regarding the scope and depth of the case study. Due to practical constraints and limited resources we were not in a position to carry out in-depth investigations into the four case cities distributed across four countries. Therefore, future research would benefit from on-site observations and interviews with key stakeholders - in public, private and civic sectors - to incorporate contextual and tacit insights on the reviewed experiments.

\section{Review of Climate Positive Development Good Practice Guide against proposed model for understanding experimentation in city networks Royal Seaport (Stockholm, Sweden)}

This project, which began in 2010, aims to transform the old industrial port area of Stockholm into a modern city environment for businesses and residents. The project demonstrates the commitment of Stockholm to sustainability, with a target to become fossil-fuel free by 2030, and is expected to accommodate 35,000 workplaces and 12,000 apartments with recreational spaces by completion.

The local governance context of Stockholm is characterised by three tiers of government: the Stockholm County Council (the regional government), the City Council (which governs the municipality City of Stockholm) and 14 district councils. While the regional government (the Stockholm County Council) oversees common-interest matters such as healthcare, public transport and regional development, the City Council is responsible for decision making, and the provision of various municipal services (including schools, housing or leisure activities) in the City of Stockholm, and the 14 
district councils govern their own respective geographic areas and deal with local regulation matters. Notably, a decentralised decision-making model is employed in Stockholm to ensure that the development of the city is aligned with the needs and desires of its residents. This means that Stockholm citizens can participate in, and contribute their opinions to, the decision-making process in relation to new policies or new infrastructure and services (City of Stockholm 2014).

\section{Elephant \& Castle (London, United Kingdom)}

The regeneration of the Elephant \& Castle site in London began in 2007, and took a significant step forward in 2013 when the Elephant Park Masterplan, which was prepared by Lendlease, received outline-planning permission. The project has attained the second stage of recognition within its progress to become climate positive with a reduction of approximately 10,000 tCO2e annually.

In the unitary country of the United Kingdom, the city governance of London is composed of two tiers: The Greater London Authority (the city-wide metropolitan government) and 33 local authorities. While the Greater London Authority is responsible for governing London and providing strategic plans and policies, 33 smaller authorities play a critical role in delivering local services, including local roads, planning regulation and social services (Nguyen et al. 2018).

\section{Barangaroo south (Sydney, Australia)}

With the aim of transforming the western edge of Sydney's central business district into a modern financial-services hub, the Barangaroo South project will accommodate more than $500,000 \mathrm{~m}^{2}$ of residential and commercial space. This development endeavours to implement energy-efficient design through the utilisation of renewable and low-carbon energy and precinct-wide infrastructure for water, cooling, power and waste management to deliver greater economies and efficiencies of scale. To date, $99 \%$ of construction waste of this development is being recycled and the Green Building Council of Australia has awarded all three commercial office towers in Barangaroo South with a 6 Star Green Star Office Design rating.

In the federation model of government of Australia, there are two tiers of governance in Sydney: the Government of New South Wales (the state government) and the City of Sydney (the local council). While the state government is responsible for metropolitan planning, public housing and services such as transport and healthcare, the local government is in charge of local policies and planning regulations, as well as local services, including road maintenance and drainage (City of Sydney 2017).

\section{Mahindra World City (Jaipur, India)}

This project, which is a public-private partnership between the Rajasthan State Industrial Development and Investment Corporation and the Mahindra Group, aims to deliver a modern business city that will be a workplace and home to more than 300,000 people. The project is expected to have a net impact of cutting more than 60,000 tCO2e annually. Additionally, the plans for the Mahindra World City endeavour to implement energy-efficiency strategies via the utilisation of renewable energy (e.g., solar) 
and sustainable transport strategies with the promotion of public and non-motorised modes of transport.

India is a federal republic, and the governance of Jaipur is composed of two tier: the State Government of Rajasthan (the state government) and the Jaipur Municipal Corporation (the municipal government). While the state government oversees key matters for the Indian state of Rajasthan (including Jaipur) such as healthcare, lands and taxation, the Jaipur Municipal Corporation is responsible for implementing administrative duties and maintaining the civic infrastructure of Jaipur. Additionally, under the Jaipur Municipal Corporation, the Jaipur Development Authority is established as a fundamental government agency that manages the planning and development of Jaipur (Jaipur Municipal Corporation 2008).

\section{Analysis of four best model projects in relation to experimentation Step 1: city experiments}

In relation to experimentation logics, neither of the four selected experiments implement controlled experimentation logics because these projects are not set-up to investigate causality and are not implemented in tightly controlled environments.

Notably, under the Climate Positive Development Program, there are 18 projects simultaneously implemented across six continents to reduce greenhouse gas emissions through a variety of innovative initiatives (e.g., constructing highly efficient buildings, promoting renewable energy and the use of waste as a resource, and providing lowcarbon mass transit solutions and more green spaces). In this sense, the implementation of collective, distributed yet parallel experimentation of those 18 projects under the Climate Positive Development Program in different countries demonstrates the emphasis on variation of climate experiments within the programme. From these 18 projects, via the Good Practice Guides, the C40 network generates a portfolio for its member cities of fit-for-purpose best practices using the four model projects discussed above. The variation of climate experiment projects and the selection of best practices substantiate the employment of a Darwinian experimentation logics in the Climate Positive Development Program.

In addition, it is acknowledged that all four best practice projects (Royal Seaport, Elephant \& Castle, Bangaroo South and Mahindra World City) are single design experiments aiming to elaborate new and innovative solutions to existing problems with a goal of success. For example, with the aim of successfully achieving energy efficiency, the solution for Elephant \& Castle is particularly innovative because it will construct a highly efficient on-site combined heat and power system to connect all buildings to heat networks, and the project will also use 'grid-injected biomethane as carbon offset' (C40 2016, p. 12). In addition, with the similar goal as the Elephant \& Castle, in the Barangaroo South project, 'innovative green leases are being utilised with commercial tenants to encourage and reward more sustainable operation of their buildings' (C40 2016, p. 13). The logic of experimentation applied by these four selected best practices is best described as generative experimentation. Thus, the C40 network is implementing a combination of Darwinian and generative experimentation through its city members under the Climate Positive Development Program. 
Moreover, in consideration of different evolution processes of urban experimentation, through the implementation of the 18 projects discussed above, it is clear that experiments in the Climate Positive Development Program have already passed the variation stage. The development of these projects is guided by the Climate Positive Framework in which development partners earn climate positive credits when reducing emissions within the local community or capturing carbon on-site through the following four different stages of recognition: (1) Stage 1-Candidate: Project application accepted; (2) Stage 2-Participant: Detailed plans approved; (3) Stage 3-Progress site: Development following roadmap; (4) Stage 4-Climate positive: Project completion (C40 2016). All these 18 projects are fully supported through four stages by the C40 network. In addition, among these 18 projects, the $\mathrm{C} 40$ conducted a survey of best practices that produce better social, economic and environmental outcomes for cities, and in the Climate Positive Development Good Practice Guide, identified four key components for successfully delivering the programme, and the following four best model projects that can become scalable and replicable models (on the basis of a performance-based framework) for other cities around the world (C40 2016, p. 3):

- set ambitious goals and implement holistic planning (this point will be illustrated through the example of Royal Seaport, Stockholm)

- create policy and regulatory frameworks to stimulate climate positive development in regeneration projects (this point will be illustrated through the example of Elephant \& Castle, London)

- employ procurement powers to promote climate positive transformation of industrial areas (this point will be illustrated through the example of Barangaroo South, Sydney)

- maximise the potential of climate positive public-private partnerships (this point will be illustrated through the example of Mahindra World City, Jaipur).

Therefore, with the influence of a combination of Darwinian and generative logics of experimentation, in the three different processes of evolution of urban experimentation [variation, selection and retention], it is clear that the experiments of Climate Positive Development Program are currently in the second stage (i.e., selection). Further, in each case study, the Good Practice Guides presents a section on 'why/when might a city adopt an approach like this', which provides useful information for transition to the implementation of these experiments, from the selection of best practices to the retention (and application) of these projects in other cities within the network (C40 2016).

\section{Step 2: how city networks relate to experiments?}

In relation to orchestration, under the Climate Positive Development Program, participating cities (with their associated projects) have come to converge around the common goals of becoming climate positive and delivering low-carbon developments. Such convergence has been generated in the $\mathrm{C} 40$ via the process of political contestation among different actors, that is, cities such as London, Stockholm, Jaipur; philanthropic organisations including Bloomberg Philanthropies; or nongovernmental organisations 
(NGOs) such as the US Green Building Council and the Clinton Foundation, which have attempted to orchestrate cities towards specific climate positive actions and joint objectives (Gordon 2013; Gordon and Johnson 2017; Gordon and Acuto 2015). With reference to Gordon and Johnson (2017), it can be considered that for all four best model projects situated in four of the $\mathrm{C} 40$ cities, the orchestration mode is 'coordinating', by which the C40 network is intermediary and the Bloomberg Philanthropies and individual cities are considered orchestrators.

In the Climate Positive Development Program, the support of US Green Building Council and the Clinton Foundation is critical to the implementation and leverage of the climate experiment projects of the $\mathrm{C} 40$ city members. The $\mathrm{C} 40$ facilitates access to the support of such organisations and also provides the fundamental institutional context for supporting the delivery of climate positive experiments and projects within the network. It is also important to note that as an intermediary, the C40 network plays an important role in the processes of selecting (and potentially retaining) best practices for participating cities in the Climate Positive Development Program through production and dissemination of the Good Practice Guides. However, there is no publicly available information showing whether the four best model projects have been leveraged elsewhere within (or outside) the network.

Further, within each best practice of the Climate Positive Development Program, a variety of actors from different domains and organisations are actively engaged, including government, NGOs, private actors, partners and citizens. For example, in the case of the Royal Seaport, the City of Stockholm, citizens and developers have been involved in the project's implementation from beginning. Additionally, the project of Mahindra World City is a public-private partnership between the Rajasthan State Industrial Development and Investment Corporation and the Mahindra Group (along with the support of State Government of Rajasthan as a partner) (C40 2016). Likewise, the local governments have collaborated with developers during the design and implementation of the Elephant \& Castle and Barangaroo South projects (C40 2016). The involvement of different actors in these projects demonstrates the complex contingencies occurring around urban experimentations in city networks.

\section{Step 3: leveraging of a local action into a global network}

In relation to the outputs of experimentation, while the four selected projects are not completed, there are several expected outputs listed in the Good Practice Guides. For example, the Royal Seaport project seeks to transform an old industrial port into a new modern city with 12,000 apartments, 35,000 workplaces and spaces for recreation to deliver a vibrant and dynamic living and workspace for both residents and businesses (C40 2016). The project will potentially create significant changes in the built environment and infrastructure surrounding the project's area. In addition, the project encourages a high degree of citizen participation and engagement, and the Royal Seaport is 'already an important part of city life' that demonstrates Stockholm's commitment to sustainability (C40 2016, p. 10). Thus, the outputs from experimentation in the Royal Seaport project are identified as built-environment change and new citizen practices.

For the Elephant \& Castle, its Masterplan's Energy Reduction Strategy for this project provides new planning practices that include the most sustainable solutions to 
accommodate future developments, for example: (1)'doubling density with zero growth in emissions'; (2)'ensuring efficient building design and technology to improve insulation and air circulation-leading to significant energy savings for residents'; (3)'building all homes with $100 \%$ controlled, responsibly-sourced FSC [Forest Stewardship Council] timber' or (4)'implementing an extensive biodiversity strategy, which will seek to restore nature on-site and help improve air quality' (C40 2016, p. 12). Additionally, the project also constructs 'a highly efficient on-site Combined Heat and Power system' to connect buildings to heat networks, which contributes to delivering infrastructural change in the area (C40 2016, p. 12). Therefore, outputs from experimentation in Elephant \& Castle project are dedicated to policy change and infrastructural change.

The Barangaroo South project constructs 'precinct-wide infrastructure for power, cooling, water and waste management' to provide 'greater efficiencies and economies of scale' (C40 2016, p. 13). Thus, the output of experimentation is identified as infrastructural change. The Mahindra World City project encourages the utilisation of renewable energy and requires 'at least $50 \%$ of rooftops dedicated to solar' (C40 2016, p. 14), which contributes to promoting the application of new energy technology. Moreover, this project promotes new planning practices to achieve sustainable transport-demonstrating the application of the 'Avoid, Shift and Improve' approach, which refers to the improvement of the transport system's efficiency through trip efficiency as well as vehicle and fuel efficiency-and the promotion of public and non-motorised modes of transport to reduce 'the overall $\mathrm{CO}_{2}$ impact from transport on-site' (C40 2016, p. 14). Consequently, outputs from experimentation in the Mahindra World City project are dedicated to new technology and policy change.

\section{Discussion and conclusion}

Urban climate governance has emerged in response to the significant and alarming phenomenon of global climate change. This new form of governance encourages urban experimentation, and this is increasingly international as cities become more connected to different peers and international actors, including city networks. Scholars observe that global city networks such as the $\mathrm{C} 40$ are effective platforms for transforming and scaling up pilot experiments into city-wide schemes (Kronsell and Mukhtar-Landgren 2018). While these networks are gaining influence, little research is engaged with more fundamental questions of how city networks condition and leverage urban experimentation - beyond the aspect of facilitating mutual learning and collaboration between cities (i.e. Lee and van de Meene 2012; Lee 2019). Our paper has contributed to investigate urban experimentation within city networks, and how these networks are in turn conditioning and leveraging urban experiments. A review of the Climate Positive Development Good Practice Guide of the C40 network has provided preliminary yet interesting insights in this regard. We have identified similarities and differences of four selected good practices and summarised these findings in Table 4.

On a more general level, the review of the Climate Positive Development Good Practice Guide yielded the following answers and insights vis-à-vis the stated research questions. First, the review has provided a more specific understanding of the nature of experiments in the C40 network. That is, we have demonstrated that the C40 network is infusing a combination of Darwinian and generative experimentation logics into its 
Table 4 Comparative analysis of four good practices against the proposed model

\begin{tabular}{|c|c|c|}
\hline \multirow[t]{2}{*}{ Step 1: City experiments } & Similarity & $\begin{array}{l}\text { - All four selected projects are not designed under controlled } \\
\text { experimentation logics, rather they use a combination of } \\
\text { Darwinian and generative experimentation logics. } \\
\text { - All four selected projects already passed the variation stage } \\
\text { and are currently in the selection stage. }\end{array}$ \\
\hline & Difference & - Not apparent \\
\hline \multirow[t]{2}{*}{$\begin{array}{l}\text { Step 2: How city networks } \\
\text { relate to experiments? }\end{array}$} & Similarity & $\begin{array}{l}\text { - All four selected projects embrace the 'coordinating' } \\
\text { orchestration mode. } \\
\text { - There are different actors from different domains and } \\
\text { organisations actively engaging in all four selected projects } \\
\text { (particularly the governments and developers). }\end{array}$ \\
\hline & Difference & $\begin{array}{l}\text { - Only the Royal Seaport demonstrates the explicit involvement } \\
\text { of citizens during the design and implementation of the project. } \\
\text { The other three projects mention only the engagement of local } \\
\text { governments and developers. }\end{array}$ \\
\hline \multirow{2}{*}{$\begin{array}{l}\text { Step 3: Leveraging of a local } \\
\text { action into a global network }\end{array}$} & Similarity & - All four experimental projects have generated outputs. \\
\hline & Difference & $\begin{array}{l}\text { - For the Royal Seaport project, the outputs are built-environment } \\
\text { change and new citizen practices. } \\
\text { - For the Elephant \& Castle project, the outputs are policy change } \\
\text { and infrastructural change. } \\
\text { - For the Barangaroo South project, the output is infrastructural } \\
\text { change. } \\
\text { - For the Mahindra World City project, the outputs are new } \\
\text { technology and policy change. }\end{array}$ \\
\hline
\end{tabular}

city members, which encourages variation in local climate actions and the generation of new and innovative climate solutions. In addition, we have found that the implementation of the four best model projects has passed the stage of 'variation', is currently in the 'selection' stage, and is moving towards the 'retention' phase in the foreseeable future.

Second, our empirical work has also elucidated the role of city networks in conditioning urban experiments. That is, under the mode of 'coordinating' orchestration, in the Climate Positive Development Program, the C40 network as an intermediary has connected participating cities (such as London, Stockholm or Jaipur) and different actors (e.g., philanthropic organisations such as Bloomberg Philanthropies and NGOs such as the US Green Building Council and the Clinton Foundation) to work together to achieve the common goals of becoming climate positive and delivering low-carbon developments. In the Climate Positive Development Program, the support of the US Green Building Council (in relation to technical knowledge) and the Clinton Foundation (in relation to financial and business expertise) is considered critical to the implementation and leverage of climate experiment projects in the C40 city members.

Third, we have acknowledged that the C40 network also provides fundamental support for the delivery of climate experiments such as the production of the Climate Positive Framework, which provides guidelines for development partners to achieve climate positive credits, including those within the process of planning or design, and have a positive influence on the surrounding community (C40 2016).

Fourth, it is apparent that via the publication of the Good Practice Guides, the C40 plays a critical role in selecting best practices, and then providing useful information (including a project summary, results, reasons for success, and particularly information on why and when a city might adopt an approach like this) to cities worldwide in relation to applying, transforming and scaling up these projects. However, there is no 
publicly available material showing whether these experiments have been leveraged elsewhere within (or outside) the network, and thus, further interviews with key policy makers or professional experts in the field are required to obtain more information about potential leverage.

Fifth, although the four selected projects are not completed, we have identified potential experimentation outputs listed in the Good Practice Guides as built-environment change, new citizen practices, policy change, infrastructural change and new technology. Our review was limited to only one report, and thus we consider that there is a need for further studies that empirically evaluate these projects to better elucidate the outputs of experiments, not only during the projects' implementation but also after the projects' completion.

In conclusion, we provide two key recommendations for further research that we think will expand our initial investigation on urban experimentation in city networks. First, as our review on the Climate Positive Development Program has focused on a very small sub-segment of climate programmes in the C40, and was limited to document analysis using secondary materials, we recommend to conduct wider studies that will ideally conduct interviews with key architects of climate experiments and projects to gain insights and information that are not publicly available.

Second, there is potential to further refine the model formulated in this research. Future study can consider new debates around post-experimentation and different sets of relevant literature, emerging around themes like urban living labs (Marvin et al. 2018) and the projectification of local governments (Fred 2015). Future research could concentrate on investigating the potential implications of experiments in city networks for traditional institutions and planning practice. That is, it is worth investigating whether urban experiments initiated via city networks can create new path dependencies illustrated through the design and implementation of better metropolitan policies to build greener, fairer and more resilient, prosperous cities. Further, the notion of how new learnings generated from experimentation in city networks are translated into conventional planning and urban management processes is relatively absent in the contemporary literature, and thus constitutes a critical gap need to be filled by future research. This might also involve the evaluation of more case studies from different experiments and projects in different networks to provide a more comprehensive understanding of the role of city networks in facilitating urban experiments.

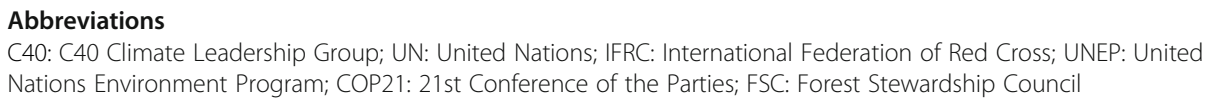


Ethics approval and consent to participate

Not applicable.

\section{Consent for publication}

Thi Minh Phuong Nguyen, Kathryn Davidson and Lars Coenen give consent for the article named 'Understanding how city networks are leveraging climate action: experimentation through C40' to be published in 'Urban Transformations'.

\section{Competing interests}

The authors declare no conflict of interest.

\section{Author details}

${ }^{1}$ Faculty of Architecture, Building and Design, The University of Melbourne, Melbourne, Australia. ${ }^{2}$ Melbourne Sustainable Society Institute, The University of Melbourne, Melbourne, Australia. ${ }^{3}$ The Mohn Centre for Innovation and Regional Development, Western Norway University of Applied Sciences, Bergen, Norway.

Received: 17 April 2019 Accepted: 4 October 2020

Published online: 14 October 2020

\section{References}

Abbott KW, Genschel P, Snidal D, Zangl B. International organizations as orchestrators. Cambridge: Cambridge University Press; 2015.

Acuto M. Global cities: governance and diplomacy. London: Routledge, Taylor \& Francis Books; 2013.

Acuto M. Give cities a seat at the top table. Nature. 2016;537:611-3.

Acuto M, Rayner S. City networks: breaking gridlocks or forging (new) lock-ins? Int Aff. 2016;92(5):1147-66.

Allen J. Powerful city networks: more than connections, less than dominance and control. Urban Stud. 2010;47(13):2895-911. Ansell C, Bartenberger M. Varieties of experimentalism. Ecol Econ. 2016;130:64-73.

Bai X, Dawson R, Ürge-Vorsatz D, Delgado G, Barau A, Dhakal S, et al. Six research priorities for cities and climate change. Nature. 2018:555:23-5.

Baxter P, Jack S. Qualitative case study methodology: study design and implementation for novice researchers. Qual Rep. 2008;13(4):544-59.

Berkhout F, Angel D, Wieczorek AJ. Asian development and sustainable sociotechnical regimes. Technol Forecasting Soc Change. 2009;76(2):218-28

Berkhout F, Verbong G, Wieczorek AJ, Raven R, Lebel L, Bai X. Sustainability experiments in Asia: innovations shaping alternative development pathways? Environ Sci Policy. 2010;13:261-71.

Bos JJ, Brown RR. Governance experimentation and factors of success in socio-technical transitions in the urban water sector. Technol Forecast Soc Chang. 2012;79:1340-53.

Bosch S. Transition experiments: exploring societal changes towards sustainability. Leiden: Erasmus University; 2010.

Bosch S, Rotmans J. Deepening, broadening and scaling up: a framework for steering transition experiments. Rotterdam: Knowledge Centre for Sustainable System Innovations and Transitions; 2008.

Bowen GA. Document analysis as a qualitative research method. Qual Res J. 2009;9(2):27-40.

Boyd E, Ghosh A. Innovations for enabling urban climate governance: evidence from Mumbai. Environ Plann C: Gov Policy. 2013;31:926-45.

Brenner N, Schmid C. The 'urban age' in question. Int J Urban Reg Res. 2014;38(3):731-55.

Broto VC, Bulkeley H. A survey of urban climate change experiments in 100 cities. Glob Environ Chang. 2013;23:92-102.

Brown H, Vergragt PJ, Green K, Berchicci L. Learning for sustainability transition through bounded socio-technical experiments in personal mobility. Tech Anal Strat Manag. 2003;15(3):291-315.

Brown HS, Vergragt PJ. Bounded socio-technical experiments as agents of systemic change: the case of a zero-energy residential building. Technol Forecasting Soc Change. 2008;75:107-30.

Bruijne M, van de Riet O, de Haan A, Koppenjan J. Dealing with dilemma's [sic]: how can experiments contribute to a more sustainable mobility system? Eur J Transp Infrastruct Res. 2010;10:274-89.

Bryman A. Social research methods. New York: Oxford university press; 2012.

Bulkeley $\mathrm{H}$. Governance and the geography of authority: modalities of authorisation and the transnational governing of climate change. Environ Plan A. 2012:44:2428-44.

Bulkeley H, Betsill M. Rethinking sustainable cities: multilevel governance and the 'urban' politics of climate change. Environ Polit. 2005;14(1):42-63.

Bulkeley H, Broto VB. Government by experiment? Global cities and the governing of climate change. Trans Inst Br Geogr. 2013;38:361-75

Bulkeley H, Edwards GAS, Fuller S. Contesting climate justice in the city: examining politics and practice in urban climate change experiments. Glob Environ Chang. 2014;25:31-40.

Bulkeley H, Kern K. Cities, Europeanization and multi-level governance: governing climate change through transnational municipal networks. J Common Mark Stud. 2009;47(2):309-32.

C40 (2013) 'Spotlight on the C40 climate positive development program' C40. Available at: https://www.c40.org/blog_posts/ spotlight-on-the-c40-climate-positive-development-program.

C40. 'Good practice guide - climate positive development' C40; 2016. p. 1-17.

C40 (2019) 'Good practice guides' C40. Available at: https://www.c40.org/other/good_practice_guides.

C40 (2020) 'Programmes'. Available at: https://www.c40.org/programmes.

Ceschin F. How the design of socio-technical experiments can enable radical changes for sustainability. Int J Des. 2014;8(3):1-21.

City of Stockholm (2014) 'Local Governance' City of Stockholm. Available at: https://international.stockholm.se/governance/ city-governance/.

City of Sydney (2017) 'Our Global City' City of Sydney. Available at: https://www.cityofsydney.nsw.gov.au/learn/research-andstatistics/the-city-at-a-glance/our-global-city. 
Coenen L, Benneworth P, Truffer B. Toward a spatial perspective on sustainability transitions. Res Policy. 2012;41(6):968-79.

Conklin J. Wicked problems \& social complexity, CogNexus institute, 2006. In: Checkland P, Poulter J, Williams T, Hitchins DK, Hoverstadt P, Pidd M, et al., editors. Dialogue mapping: building shared understanding of wicked problems. Chichester: Wiley; 2006

Davidson K, Coenen L, Acuto M, Gleeson B. Reconfiguring urban governance in an age of rising city networks: a research agenda. Urban Stud. 2019;56(16):3540-55.

Davidson K, Gleeson B. Interrogating urban climate leadership: toward a political ecology of the C40 network. Glob Environ Polit. 2015;15(4):21-38

Evans J, Karvonen A, Raven R, editors. The experimental city. New York: Routledge; 2016.

Frantzeskaki N, Broto VC, Coenen L, Loorbach D, editors. Urban sustainability transitions. New York: Routeledge; 2017.

Fred M. Projectification in Swedish municipalities. A case of porous organizations. Scand J Public Admin. 2015;19(2):49-62

Fuenfschilling L, Binz C. Global socio-technical regimes. Res Policy. 2018;47(4):735-49.

Fuenfschilling L, Frantzeskaki N, Coenen L. Urban experimentation \& sustainability transitions. Eur Plan Stud. 2019;27(2):219-28

Geels F. From sectoral systems of innovation to socio-technical systems: insights about dynamics and change from sociology and institutional theory. Res Policy. 2004;33(6-7):897-920

Gordon D, Acuto M. If cities are the solution, what are the problems? The promise and perils of urban climate leadership. In: Johnson C, Schroeder H, Toly N, editors. The urban climate challenge: rethinking the role of cities in the global climate regime. New York: Routledge; 2015. p. 63-81.

Gordon DJ. Between local innovation and global impact: cities, networks, and the governance of climate change. Can Foreign Policy J. 2013;19:288-307.

Gordon DJ, Johnson CA. The orchestration of global urban climate governance: conducting power in the post-Paris climate regime. Environ Polit. 2017;26(4):694-714

Hale T. "All hands on deck": the Paris agreement and nonstate climate action. Glob Environ Polit. 2016;16(3):12-22.

Haselmayer S. The De-Globalized City. New Glob Stud. 2018;12(1):65-73.

Heijden JVD. Experimental governance for low-carbon buildings and cities: value and limits of local action networks. Cities. 2016;53:1-7.

Heikkinen M, Ylä-Anttila T, Juhola S. Incremental, reformistic or transformational: what kind of change do C40 cities advocate to deal with climate change? J Environ Policy Plann. 2019;21(1):90-103.

Heilmann S. Policy experimentation in China's economic rise. Stud Comp Int Dev. 2008:43:1-26.

Heine J. On the manner of practising the new diplomacy. In: Cooper AF, Hocking B, Maley W, editors. Global governance and diplomacy: worlds apart? London: Palgrave; 2008. p. 273.

Hodson M, Marvin S. Urbanism in the anthropocene: ecological urbanism or premium ecological enclaves? City. 2010;14(3): 299-312.

Hoffmann MJ. Climate governance at the crossroads - experimenting with a global response after Kyoto. New York: Oxford University Press; 2011.

Hoogma R, Kemp R, Schot J, Truffer B. Experimenting for sustainable transport. The approach of strategic niche management. London: E\&F Spon Publisher (Routledge); 2002.

Hopkins R. The transition handbook: from oil dependency to local resilience. Totnes, Devon: Green Books; 2008.

IFRC. World disasters report (2010): focus on urban risk. Geneva: IFRC; 2010. p. 1-220.

Jaipur Municipal Corporation. Urban governance and institutional framework; 2008. p. 1-19. Available at: http:/jaipurmc.org/ PDF/Auction_MM_RTI_Act_Etc_PDF/11-Chapter-11.pdf.

Jordan A, Huitema D, Hilden M, van Asselt H, Rayner TJ, Schoenefeld JJ, et al. Emergence of polycentric climate governance and its future prospects. Nat Clim Chang. 2015;5:977-82.

Kemp R, Schot J, Hoogma R. Regime shifts to sustainability through processes of niche formation: the approach of strategic niche management. Tech Anal Strat Manag. 1998;10(2):175-98.

Kivimaa P, HildéN M, Huitema D, Jordan A. Experiments in climate governance - a systematic review of research on energy and built environment transitions. J Clean Prod. 2017;169:17-29.

Kronsell A, Mukhtar-Landgren D. Experimental governance: the role of municipalities in urban living labs. Eur Plan Stud. 2018; 26(5):988-1007.

Laakso S, Berg A, Annala M. Dynamics of experimental governance: a meta-study of functions and uses of climate governance experiments. J Clean Prod. 2017;169:8-16.

Leahy S. From not enough to too much, the world's water crisis explained. Natl Geogr. 2018; Retrieved from https://news. nationalgeographic.com/2018/03/world-water-day-water-crisis-explained/.

Lee T. Global cities and transnational climate change networks. Glob Environ Polit. 2013;13(1):108-27.

Lee T. Network comparison of socialization, learning and collaboration in the C40 cities climate network. J Environ Policy Plan. 2019;21(1):104-15.

Lee T, van de Meene S. Who teachs and who learns? Policy learning through the C40 cities climate network. Policy Sci. 2012; 45:199-220.

Leffel B, Acuto M. Economic power foundations of cities in global governance. Glob Soc. 2018:1-21. https://doi.org/10.1080/ 13600826.2018.1433130.

Loorbach D, Shiroyama $\mathrm{H}$. The challenge of sustainable urban development and transforming cities. In: Anonymous governance of urban sustainability transitions. Tokyo: Springer; 2016. p. 3-12.

Marvin S, Bulkeley H, Mai L, McCormick K, Palgan YV, editors. Urban living labs: experimenting with city futures. London: Routledge; 2018.

McGuirk P, Dowling R, Brennan C, Bulkeley H. Urban carbon governance experiments: the role of Australian local governments. Geogr Res. 2015;53:39-52.

Merriam SB. Qualitative research: a guide to design and implementation. San Francisco: Jossey-Bass; 2009.

Moore T, de Haan F, Horne R, Gleeson B. Urban sustainability transitions: Australian cases - international perspectives. Singapore: Springer; 2018.

Nevens F, Frantzeskaki N, Gorissen L, Loorbach D. Urban transition labs: co-creating transformative action for sustainable cities. J Clean Prod. 2013;50:111-22. 
Nguyen TMP, Davidson K, Gleeson B. Metropolitan strategies and climate governance: towards new evaluative approaches. Int J Urban Reg Res. 2018;42(5):934-51. https://doi.org/10.1111/1468-2427.12662.

Parks D. Energy efficiency left behind? Policy assemblages in Swedeńs most climate smart city. Eur Plan Stud. 2019;27(2):318-35.

Partzsch L. 'Power with' and 'power to' in environmental politics and the transition to sustainability. Environ Polit. 2017;26(2): 193-211.

Punch KF. Introduction to social research: quantitative and qualitative approaches. London: Sage; 2013.

Raven R, Sengers F, Spaeth P, Xie L, Cheshmehzangi A, Jong M. Urban experimentation and institutional arrangements. Eur Plan Stud. 2019;27(2):258-81.

Sabel CF, Zeitlin J. Experimentalist governance: the Oxford handbook of categories; 2012.

Sengers F, Wieczorek A, Raven R. Experimenting for sustainability transitions: a systematic literature review. Technol Forecasting Soc Change. 2019;145:153-64.

Seyfang G, Smith A. Grassroots innovations for sustainable development: towards a new research and policy agenda. Environ Polit. 2007;16(4):584-603.

Smeds E, Acuto M. Networking cities after Paris: weighing the ambition of urban climate change experimentation. Glob Policy. 2018;9(4):549-59.

Smith A, Raven R. What is protective space? Reconsidering niches in transitions to sustainability. Res Policy. 2012;41 (6):1025-36

Sotarauta M, Srinivas S. Co-evolutionary policy processes: understanding innovative economies and future resilience. Futures. 2006;38(3):312-36

Stoker G, John P. Design experiments: engaging policy makers in the search for evidence about what works. Polit Stud. 2009: 57:356-73.

Tollin N. The role of cities and local authorities following COP21 and the Paris Agreement. Sustainable. 2015;16(1):43-51.

Turnheim B, Kivimaa P, Berkhout F. Innovating climate governance: moving beyond experiments. United Kingdom: Cambridge University Press; 2018.

U.S. Green Building Council (2020) 'Climate positive development program'. Available at: https://www.usgbc.org/resources/ climate-positive-development-program.

UN. 'World Urbanization Prospects'. 10 February 2018: New York: United Nations; 2014. p. 1-32. Available at: https://esa.un. org/unpd/wup/publications/files/wup2014-highlights.pdf.

UN. The World's cities in 2016 - Data Booklet (ST/ESA/ SER.A/392). 15 February 2018: United Nations; 2016. Available at: http:// www.un.org/en/development/desa/population/publications/pdf/urbanization/the_worlds_cities_in_2016_data_booklet. pdf.

UNEP\&UN-HABITAT (2009) 'Climate change - the role of cities: involvement, influence, implementation' UNEP. Available at: < http://www.unep.org/urban_environment/PDFs/RoleofCities_2009.pdf>. (Accessed 17 May 2016).

UN-HABITAT. Cities and climate change: Global report on human settlements 2011. London: United Nations Human Settlements Programme; 2011. p. 1-300.

Vergragt P, Brown HS. Sustainable mobility: from technological innovation to societal learning. J Clean Prod. 2007;15(11-12): 1104-15.

Weber M, Hoogma R, Lane B, Schot J. Experimentingwith sustainable transport innovations: a workbook for strategic niche management. Sevilla/Enschede: IPTS/University of Twente; 1999

Wieczorek A, Raven R, Berkhout F. Transnational linkages in sustainability experiments. The case of solar PV in India. Environ Innov Societal Transitions. 2015;17:149-65.

Wright, I. (2018). Cape Town is almost out of water. Could Australian cities suffer the same fate? The conversation. Retrieved from https://theconversation.com/cape-town-is-almost-out-of-water-could-australian-cities-suffer-the-same-fate-90933.

Yin RK. Case study research: design and methods. Thousand Oaks: SAGE; 2014.

\section{Publisher's Note}

Springer Nature remains neutral with regard to jurisdictional claims in published maps and institutional affiliations.

Ready to submit your research? Choose BMC and benefit from:

- fast, convenient online submission

- thorough peer review by experienced researchers in your field

- rapid publication on acceptance

- support for research data, including large and complex data types

- gold Open Access which fosters wider collaboration and increased citations

- maximum visibility for your research: over $100 \mathrm{M}$ website views per year

At $B M C$, research is always in progress.

Learn more biomedcentral.com/submissions 